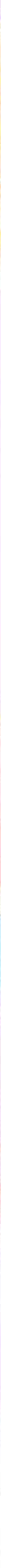




\section{EVOLUCIONISMO E MORALIDADE:}

\section{contribuições filosóficas}

\section{LEONARDO DE MELLO RIBEIRO*}

RESUMO Para a filosofia moral, uma descrição evolucionista da psicologia e do comportamento humanos pode ser bastante esclarecedora quanto à natureza da moralidade e quanto à importância que o fenômeno moral adquire em nossas vidas. Neste artigo, abordaremos o tema considerando a seguinte questão: supondo que a moralidade seja um resultado adaptativo de nossa espécie, o que isso nos revela sobre o status de nossos juízos morais? Tomaremos, como resposta, a hipótese segundo a qual a teoria evolucionista é capaz de explicar, mas não justificar, nossos juízos morais. Correntes filosóficas distintas serão exploradas na investigação do que tal explicação nos revelaria acerca dos compromissos ontológicos, semânticos e epistemológicos do discurso moral.

PALAVRAS-CHAVE Evolucionismo. Moralidade. Filosofia Moral.

\section{EVOLUTIONISM AND MORALITY: philosophical contributions}

ABSTRACT Considering that, for moral philosophy, an evolutionary description of human psychology and behaviour can shed considerable light on the nature of morality and the importance that the moral phenomenon assumes in our lives, the following question is posed: assuming that morality is an adaptive product of our species, what can be inferred from the status of our moral judgements? Departing from the hypothesis that the evolutionary theory can explain, but not justify our moral judgements, different philosophical trends are investigated in an effort to find out what such an explanation would reveal in terms of ontological, semantic and epistemological commitments of the moral discourse.

KEYWORDS Evolutionism. Morality. Moral philosophy.

* Professor do Departamento de Filosofia, Faculdade de Filosofia e Ciências Humanas, Universidade Federal de Minas Gerais (UFMG)

E-mail: ribeiro.Im@gmail.com

Recebido em 30/09/2014. Aprovado em 01/10/2014. 


\section{Introdução}

1. Nagel, 1978, p. 196.

2. Ao longo de todo este artigo, usaremos as palavras 'ética' e 'moralidade' como sinônimas.

3. Nagel, Op.Cit., p. 196.
$\mathrm{T}$ homas Nagel disse que "a utilidade de uma abordagem biológica à ética depen-

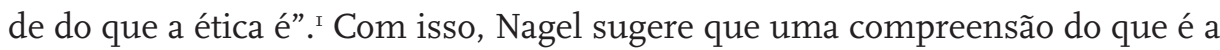
ética ou a moralidade deve anteceder uma investigação da natureza humana fornecida pela biologia (na verdade, por qualquer ciência particular). ${ }^{2}$ Em um sentido, a afirmação de Nagel é trivialmente correta. Obviamente, precisamos tomar conceitualmente como ponto de partida ao menos uma caracterização geral do que é a moralidade antes de sermos capazes de avaliar as suas implicações. Porém, Nagel parecia querer dizer mais do que isso, pois ele sugere também que essa concepção primária do que é a moralidade é fixa a ponto de não estar sujeita a qualquer tipo de revisão ou adequação resultantes de investigações empíricas. Nagel defende que a moralidade é uma disciplina teoreticamente autônoma, cuja investigação acerca de seus compromissos mais fundamentais independe dos resultados das ciências particulares.

Nagel admite que se a moralidade fosse "um certo tipo de padrão comportamental ou hábito, acompanhado de algumas respostas emocionais, as teorias biológicas poderiam nos ensinar muito sobre ela." 3 Mas ele simplesmente nega que isso seja uma caracterização adequada da moralidade. Para Nagel, essa é "uma investigação teórica que 4. Ibid. pode ser abordada por métodos racionais com padrões internos de justificação e crítica"4, o que reduz drasticamente a relevância de investigações empíricas para a moralidade.

Entretanto, o que não parece ter ocorrido a Nagel é a possibilidade de que, embora estejamos dispostos a admitir que há algo central em nosso entendimento do que seja a moralidade que não parece ser fornecido pelas investigações empíricas das ciências particulares, essas investigações podem contribuir significativamente para uma ampliação ou revisão de parte dos nossos compromissos conceituais iniciais acerca da moralidade. Somente se mantivermos "inegociável” a nossa caracterização inicial do que seja a moralidade, é que poderemos descartar de antemão qualquer contribuição empírica das ciências particulares. No entanto, uma atitude como essa pareceria, no 
mínimo, dogmática. Devemos manter em aberto a possibilidade de que estudos empíricos sobre a psicologia e o comportamento humanos possam redimensionar nossa concepção inicial de moralidade e, ao mesmo tempo, preservar outros elementos que nos permitem continuar a reconhecer o mesmo fenômeno como moral. Nesse sentido, contrariamente à sugestão de Nagel, talvez seja compatível entender a moralidade como "um tipo de padrão comportamental ou hábito, acompanhado de algumas respostas emocionais" e "uma investigação teórica que pode ser abordada por métodos racionais e que possui padrões internos de justificação e crítica”. Doravante, exploraremos essa proposta à luz das contribuições que a moderna teoria evolucionista, de inspiração Darwinista, tem a oferecer sobre a psicologia e o comportamento humanos.

\section{Antecedentes históricos}

O fato de propor uma descrição genealógica da natureza humana (sobretudo de suas capacidades cognitivas, afetivas e sociais) já parece constituir razão suficiente para que a teoria evolucionista mereça atenção de diversas áreas do conhecimento humano, mas isso nem sempre aconteceu. A validade e a relevância das contribuições da teoria nunca estiveram, desde o seu surgimento, livres de controvérsia. E é verdade que os críticos da teoria tiveram motivos para rejeitá-la ou tomá-la como suspeita, dados os excessos inaceitáveis cometidos por seus defensores na primeira metade do século XX. ${ }^{5}$

A despeito disso, nosso ponto de partida será conceder hipoteticamente validade à teoria evolucionista, de uma perspectiva geral. Suponhamos que ela esteja correta em linhas gerais. O que ela nos diz sobre a vida social humana? Em particular, o que ela nos diz sobre o fenômeno moral? Em um primeiro momento, não foram raras as respostas excessivamente entusiásticas a essas perguntas. Em sua forma extrema, ela consistia em dizer “Tudo!”. O mais emblemático representante dessa resposta talvez tenha sido Herbert Spencer. Spencer parecia acreditar que poderíamos extrair da teoria evolucionista não apenas uma explicação da origem da moralidade, mas também uma justificação para ela, com base nos princípios explicativos da seleção natural. Em outros termos, Spencer parecia crer que a teoria evolucionista poderia tanto revelar por que a moralidade faz parte de nossas vidas quanto servir como guia (normativo) para conduzir nosso modo de viver.
5. Como diz Ruse: "tentativas de entender a moralidade a partir de nossas naturezas brutas funcionaram, de modo muito frequente como apologia disfarçada para ideologias reacionárias e insensíveis." (Ruse, 1984, p. 167) Assim, não foram incomuns as acusações de sexismo, racismo, elitismo, entre outros, a determinadas conclusões extraídas de versões passadas da teoria evolucionista. 
Isso constitui, obviamente, um projeto ambicioso e, como tal, sofreu fortes críticas tão logo surgiu (a mais importante delas formulada por G. E. Moore). Como veremos, o que podemos seguramente dizer é que tais críticas são relevantes por identificarem a falta de cuidado de propostas como a de Spencer.

Adeptos da posição de Spencer passaram a ser chamados, na primeira metade do século XX, de darwinistas sociais. Embora, de modo espantoso, tenham conseguido crédito de parte da comunidade científica e de setores influentes das sociedades ocidentais (a ponto de algumas de suas ideias terem-se tornado objeto de políticas públicas estatais, como a eugenia), darwinistas sociais nunca conseguiram se livrar de críticas ferozes (sobretudo das várias vertentes das ciências humanas).

Na década de 60 e, mais notavelmente, na década de 70, um movimento nos estudos evolucionistas surgiu a fim de tentar corrigir equívocos do darwinismo social, ao mesmo tempo em que propunha apresentar a relevância da teoria evolucionista para as ciências humanas. A sociobiologia surgiu fundamentalmente como uma descrição da origem do comportamento animal social (incluindo o ser humano), sem ter como compromisso geral (ao menos, não explicitamente) tomar a teoria evolucionista também como guia normativo para a vida humana.

Sociobiólogos obtiveram um reconhecimento ligeiramente superior ao atribuído a darwinistas sociais entre algumas vertentes das ciências humanas. Ainda assim, enfrentaram obstáculos similares aos enfrentados por darwinistas sociais diante das Em particular, o que uma explicação evolucionista do fenômeno moral nos revela sobre os compromissos ontológicos, semânticos e epistemológicos de nossos juízos morais? correntes mais tradicionais das ciências humanas. Por outro lado, a sociobiologia (e a psicologia evolutiva, como desdobramento mais recente da sociobiologia) despertou em parte da literatura filosófica uma retomada do interesse pelos estudos evolucionistas que, com algumas exceções ao longo do século XX, manteve-se latente desde os ataques de Moore a Spencer. Sobretudo a partir da década de 8o, as contribuições que a teoria evolucionista poderia fornecer para uma melhor compreensão do fenômeno moral voltaram à agenda das discussões filosóficas. 
Um fato recorrente na literatura filosófica, desde então, tem sido perguntar: com base na pressuposição de que a moralidade seja um resultado adaptativo de nossa espécie, o que isso nos revela sobre o status de nossos juízos morais? Em particular, o que uma explicação evolucionista do fenômeno moral nos revela sobre os compromissos ontológicos, semânticos e epistemológicos de nossos juízos morais? Tendo nossos juízos morais sido originados por um processo (não teleológico) como o da seleção natural, eles podem possuir a função de representar uma realidade objetiva, externa a nós? Se sim, como podemos justificar nossos juízos morais se eles, como um dado de nossa psicologia, são resultado do processo da seleção natural (que, à primeira vista, tem uma relação direta, não com a moralidade, mas com sobrevivência e reprodução de um organismo)? Se não, qual é a função de nossos juízos morais e qual a relevância de descobrirmos que eles são oriundos de um processo evolutivo?

Questões como essas serão abordadas em nossa discussão a seguir. Porém, antes de considerarmos possíveis respostas a elas, faremos, nas duas próximas seções, considerando antecedentes histórico-filosóficos, um breve percurso explicativo do quadro representativo da discussão filosófica contemporânea sobre o tema.

\section{O legado de Moore}

Em I879, em uma das primeiras tentativas de extrair conclusões sobre o fenômeno moral na vida humana, com base em premissas orientadas exclusivamente pela teoria evolucionista, Spencer, em seu The Data of Ethics, defendeu que

A verdade segundo a qual o homem idealmente moral é alguém em quem o equilíbrio que o move é perfeito, ou se aproxima o máximo da perfeição, torna-se, quando traduzida para a linguagem fisiológica, a verdade de que ele é alguém em quem as funções de todos os tipos são adequadamente realizadas. Cada função possui alguma relação, direta ou indireta, com as necessidades da vida [...].

$[\ldots]$

Assim, o homem moral é aquele cujas funções [...] são todas deflagradas em graus adequadamente ajustados às condições de sua existência. Embora pareça estranha, essa conclusão é a conclusão a ser extraída aqui, a de que a realização de toda função é, em um sentido, uma obrigação moral. ${ }^{6}$

6. Spencer, 1879, p. 75-76. 
7. O objetivo com essas passagens não é tomá-las como sínteses precisas do pensamento de Spencer, mas ilustrar uma determinada proposta (historicamente relevante) de se entender a relação entre evolucionismo e moralidade.
Para que essas passagens alcancem o impacto que pretendiam, devemos fazer notar que Spencer, ao usar os conceitos “função”, “necessidades da vida” e “equilíbrio", tem em mente interpretações puramente biológicas desses conceitos, tal como aparecem na teoria evolucionista.7 Assim, Spencer foi tomado como defensor de que podemos reduzir conceitos morais e proposições morais a conceitos e proposições fornecidos pela teoria evolucionista. Com base nessa interpretação, Spencer tornouse uma figura emblemática que conferiu uma reputação duvidosa aos estudos que se propunham a investigar a relação entre evolucionismo e moralidade.

Por que passagens como aquelas conferiram ao tipo de estudo ao qual Spencer estava associado uma reputação duvidosa? Uma leitura atenta daquelas passagens revela que elas são enunciados pouco cuidadosos sobre as possíveis relações entre evolucionismo e moralidade. Podemos destacar algumas dificuldades centrais: (a) a passagem direta de um vocabulário típico das ciências naturais (em particular, da biologia evolucionista) para um vocabulário normativo moral; (b) a aparente pressuposição de que ordenamento normativo implica e é implicado por ordenamento funcional (biológico); (c) a tese de que o fim último da vida humana pode ser explicado com referência à preservação da existência, sob uma perspectiva evolucionista.

Diante desse diagnóstico, tão logo filósofos debruçaram-se sobre propostas como a de Spencer, os ataques se iniciaram. Um dos mais famosos deles surgiu já na virada para o XX, em I903, com G. E. Moore e seu Principia Ethica. O ataque de Moore não se limitava à proposta de ética evolucionista de Spencer, mas é muito provável que a obra de Spencer tenha sido uma das principais motivações de Moore. Isso não apenas porque Moore dedica um capítulo inteiro a discutir e a rejeitar propostas como a de Spencer, mas também porque decidiu nomear de “naturalista” uma suposta falácia que várias escolas filosóficas de pensamento moral cometiam, em uma clara alusão ao projeto de naturalização da ética proposto por Spencer. ${ }^{8}$

É provável que Moore não tenha sido inteiramente justo com Spencer na caracterização de sua proposta de naturalização da ética. Mas o fato é que grande parte da tradição filosófica posterior a Moore tomou suas palavras como a caracterização padrão daquilo que se passou a chamar de ética evolucionista. Segundo essa caracterização, defensores de uma ética evolucionista seriam propriamente descritos como reducionistas, naturalistas e evolucionistas. Eles seriam reducionistas porque propõem uma redução do vocabulário 
ético a um vocabulário de outra natureza; seriam naturalistas porque propõem que o vocabulário relevante para substituir o vocabulário ético seria o vocabulário da(s) ciência(s) natural(is); seriam evolucionistas porque propõem especificamente que a ciência adequada a cumprir esse papel é a biologia, por meio de sua abordagem evolucionista.

A suposta falácia que Moore identificou pode ser resumida nos seguintes termos: toda e qualquer proposta de redução (ou identificação) do vocabulário moral a um vocabulário de outra natureza pode ser inteligivelmente questionada. Isso porque, para toda e qualquer proposta de identificação do vocabulário moral com um vocabulário de outra natureza, uma questão que refute a veracidade de tal identificação não envolve qualquer tipo de confusão conceitual e, portanto, tem sua resposta em aberto. Em uma proposta como a da ética evolucionista, o ataque de Moore poderia, então, ser formulado do seguinte modo: o defensor de uma ética evolucionista proporia que um termo moral fundacional - como "bom", "correto" ou "dever" - fosse definido nos termos fornecidos pela teoria da evolução. Assim, 'bom', por exemplo, poderia ser "aquilo que garante a preservação e a reprodução de um indivíduo da espécie humana”. O argumento de Moore, então, foi o de que qualquer proposta nessa direção poderia ser inteligivelmente questionada: “x é algo que garante a preservação e a reprodução de um indivíduo da espécie humana, mas x é bom?” Essa é, para Moore, uma questão inteligível e cuja resposta está em aberto - que não pode ser respondida por meio de uma mera análise dos conceitos contidos nela. Mas, segundo Moore, se termos éticos pudessem ser reduzidos a termos fornecidos pela teoria da evolução, tal questão não seria inteligível. Ela envolveria algum tipo de confusão conceitual, da mesma forma que (supostamente) alguém estaria conceitualmente confuso se perguntasse se um solteiro é um homem não casado, sendo esse conceito uma verdade conceitual e, como tal, envolvendo a identificação dos termos "solteiro" e "homem não casado". ${ }^{9}$

A suposta falácia que Moore identificou carrega várias dificuldades. Moore, naturalmente, não vislumbrou a possibilidade de que linguagem e metafísica pudessem não ser inteiramente coincidentes ${ }^{\mathrm{IO}}$ e ainda parecia cometer a petição de princípio de excluir a possibilidade de que o naturalista reducionista estivesse correto e, portanto, pudesse considerar como confuso conceitualmente alguém que questionasse a sua proposta de iden-

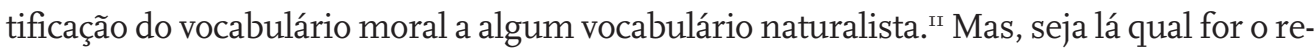
sultado dessa disputa filosófica, o que Moore certamente deixou como importante legado
9. Deixemos aqui de lado a discussão filosófica que põe em questão a existência de verdades analíticas.

10. De fato, propostas semânticas posteriores, pós-Kripke e pós-Putnam, são frequentemente usadas por defensores contemporâneos de uma naturalização da ética. Nesse caso, ainda que nosso vocabulário moral não revele qualquer relação conceitual interessante com - vocabulário das ciências naturais, poderia, ainda assim, ser o caso que ambos os vocabulários se referissem às mesmas propriedades. Infelizmente, não teremos a oportunidade de explorar aqui propostas como essa. 11. Como disse Frankena, "a acusação de se cometer a fa lácia naturalista só pode ser feita como uma conclusão da discussão e não como um instrumento para decidi-la." (1939, p. 465) 
12. Ao dizer isso, descartamos como parte dos nossos objetivos aqui explorar alternativas segundo as quais propostas mais detalhadas, mas que preservassem o espírito da tese de Spencer, pudessem ser defendidas.

13. Uma instrutiva discussão desses movimentos e de seus reflexos na filosofia pode ser encontrada em Ruse, 1986a. em relação às primeiras propostas de ética evolucionista foi tornar claro quão simplório e questionável seria propor que, considerando o fato de que se tem disponível uma história explicativa sobre a origem e desenvolvimento biológico da vida humana, poder-se-ia inferir diretamente, com base nisso, ditames específicos (morais) sobre como conduzir a vida humana. Isso, por si só, não inviabiliza conceitualmente uma proposta como a de Spencer, mas exige que ela forneça muito mais premissas a seu argumento para que ele possa funcionar. Em especial, propostas de uma ética evolucionista precisariam mostrar como seria possível, partindo de uma história genealógica explicativa sobre a origem do comportamento humano, justificar o conteúdo da moralidade e como devemos agir. ${ }^{\text {I2 }}$

\section{Sociobiologia e psicologia evolucionista}

Após uma diminuição de interesse filosófico na temática, a discussão sobre a contribuição que a teoria evolucionista poderia oferecer para o entendimento do fenômeno moral volta a ganhar força a partir da década de 8o. Esse movimento filosófico é, na verdade, reflexo de outros movimentos em biologia, psicologia, ciência cognitiva, antropologia e em outras disciplinas. ${ }^{13}$ Com a publicação de Sociobiology: The New Synthesis, por E. O. Wilson, em I975, surge, de modo sistemático, a proposta de um novo paradigma para a compreensão do comportamento humano, com base nas hipóteses da então chamada "sociobiologia". O trabalho de Wilson incorpora os avanços sobre a teoria evolucionista promovidos, na década de 6o, por autores como J. Maynard Smith, W. D. Hamilton, G. C. Williams, entre outros. Esses autores foram responsáveis por uma elucidação do conceito de adaptação na tradição darwinista (e de conceitos fundamentais relacionados, como adaptação inclusiva e seleção por parentesco) e também por fornecer uma base matemática para ela. Mas é Wilson que, na esteira dessa literatura, sistematiza e populariza a ideia de explicar o comportamento social, sustentado por bases biológicas evolucionistas.

De forma resumida, segundo a sociobiologia, os genes dos animais (humanos e não humanos) ocupam um papel central na explicação do comportamento, em especial, do comportamento social. A ideia é que comportamentos sociais que moldaram o passado evolutivo dos animais, tais como padrões de acasalamento, disputas territoriais, buscas por alimentos em grupo, agressividade, altruísmo, reciprocidade, 
entre outros, são considerados traços que foram selecionados em razão de pressões adaptativas que os indivíduos sofreram em seus ambientes. Essas pressões adaptativas levaram alguns animais, em variados graus de complexidade, a desenvolver formas de interações sociais que garantissem perpetuação genética por meio da sua sobrevivência e da maximização de sua capacidade reprodutiva. Nas palavras de Wilson:

O âmago da hipótese genética é a proposição, derivada diretamente da teoria evolucionista neo-Darwnista de que os traços da natureza humana foram adaptativos durante o período em que a espécie humana evoluiu e que os genes consequentemente se espalharam através da população, que predispôs os seus portadores a desenvolverem aqueles traços. Adaptabilidade significa simplesmente que se um indvíduo possuísse os traços ele teria uma maior chance de ter seus genes representados na próxima geração do que se não possuísse os traços. A diferença de vantagem entre indivíduos é chamada, nesse sentido estrito, de adaptação genética. Há três componentes básicos da adaptação genética: aumento da sobreviência individual, aumento da reprodução pessoal e melhoria da sobrevivência e reprodução de parentes próximos que compartilham os mesmos genes por descendência direta. Uma melhoria em qualquer um dos fatores ou em qualquer combinação deles resulta em uma maior adaptação genética. [...] Se a posse de certos genes predispõe indivíduos em relação a um traço em particular, por exemplo, um certo tipo de resposta social, e o traço, por sua vez, confere adaptação superior, os genes ganharão um aumento em sua representação na próxima geração. Se a seleção natural continua por muitas gerações, os genes favorecidos se espalharão por toda a população, e o traço se tornará uma característica da espécie. É dessa forma que muitos sociobiólogos, antropólogos e outros postulam que a natureza humana foi moldada pela seleção natural.14

Como mencionamos anteriormente, a sociobiologia, como uma disciplina aplicada à vida humana, nunca recebeu endosso unânime das várias correntes das ciências humanas. Isso se deu fundamentalmente porque se atribuiu à sociobiologia uma visão estreita da natureza humana e da sua vida social. Essa rejeição pode ser explicada, em parte, por culpa dos próprios sociobiólogos. Embora possa não ter sido intenção deles, a verdade é que pairava no ar uma falta de cuidado na apresentação de suas propostas, além de uma postura altamente ambiciosa, ${ }^{15}$ que dava margem a interpretações da sociobiologia como defendendo alguma forma de determinismo genético que, na melhor das hipóteses, não parecia acomodar bem o papel fundamental que a cultura tem na vida humana. ${ }^{6}$ Parece especialmente problemática a explicação de certos traços comportamentais como sendo adaptativos. Para citar apenas dois casos, a maneira como
14. Wilson, 1978, p. 32-3. 15. Wilson diz, por exemplo: "cientistas e humanistas devem considerar a possibilidade de que chegou a hora de a ética ser removida temporariamente das mãos dos filósofos e ser biologizada." (Wilson, 1975, p. 287) E nega a possibilidade de que a moralidade, como fenômeno cultural, possa se tornar autônoma de sua base biológica: "Os genes mantêm a cultura presa a uma correia. A correia é bastante longa, mas inevitavelmente os valores sofrerão a influência de seus efeitos sobre a distribuição do gene humano. [...] $\bigcirc$ comportamento humano [...] é a técnica indireta através da qual o material genético humano foi e será mantido intacto. Não é possível demonstrar qualquer outra função última para a moralidade." (Wilson, 1978, p. 167)

16. Segundo Wilson: "a questão relevante não é mais se o comportamento social humano é geneticamente determinado; [a questão] é até que ponto ele é." (Wilson, 1978, p. 19) Mas, ao mesmo tempo, reconhece que apenas nos humanos "a cultura se infiltrou de modo completo em virtualmente todo aspecto da vida. Os detalhes etnográficos são subdeterminados, resultando em grande diversidade entre as sociedades.

Subdeterminação não significa que a cultura esteja livre dos genes. O que evoluiu foi a capacidade para a cultura [...]." (Wilson, 1975, p. 284) E ainda que "a evolução social humana é obviamente mais cultural do que genética." (Wilson, 1978, p.153) 
17. Cf. Wilson (1978, p. 39ss. e cap.7) para suas discussões sobre hipergamia e altruísmo recíproco

18. Em particular, a obra de Barkow, Tooby e Cosmides ocupa um lugar central na sistematização da disciplina. Ver Barkow, Tooby e Cosmides (1992) para uma série de artigos sobre o tema.
Wilson e os pioneiros da sociobiologia explicam o que eles chamam de "altruísmo recíproco" e "hipergamia” parece, no mínimo, superficial. O problema não é apenas que não parece apropriado usar conceitos como “altruísmo" e "hipergamia” para padrões orgânicos que são explicados geneticamente, mas fundamentalmente que não é feita uma distinção clara, na literatura sociobiológica, entre o uso metafórico (que deveria ser o propósito da sociobiologia) e o uso literal (tipicamente humano) de tais conceitos. ${ }^{\text {T7 }}$

É da constatação de várias imprecisões como essas na literatura sociobiológica que surge um novo movimento em psicologia que, embora associado ao ideal da sociobiologia de uma explicação biológica evolucionista da vida social humana, dispõe-se a explorar de modo mais rigoroso o tema e a responder as objeções à sociobiologia.

A psicologia evolutiva, consolidada na década de 80, propõe-se não apenas a ser uma disciplina mais ampla do que a sociobiologia, mas também a explicar aspectos do comportamento humano que apresentavam dificuldades para os textos pioneiros da sociobiologia. A psicologia evolutiva é uma disciplina mais ampla do que a sociobiologia porque ela se propõe primariamente a investigar os mecanismos mentais (e complexos neurais) responsáveis pelo comportamento humano em geral, sob uma perspectiva evolucionista e igualmente informada por modelos computacionais de explicação do funcionamento da mente humana (que foram herdados dos avanços obtidos nas ciências cognitivas inspirados pelo paradigma Chomskiano dos mecanismos inatos subjacentes ao aprendizado da linguagem). ${ }^{18}$ Assim, o escopo da psicologia evolutiva não é restrito ao comportamento social, mas envolve todo tipo de comportamento e capacidades cognitivas e afetivas, humanas em geral. Além disso, e de modo mais fundamental, o foco da psicologia evolutiva reside nos mecanismos adaptativos da mente humana para explicar o comportamento, e não diretamente nos comportamentos. A sociobiologia tendia, ao contrário, a concentrar-se apenas em padrões comportamentais e, como tal, parecia conceder pouco espaço para a flexibilidade das capacidades humanas. É por concentrar-se nos mecanismos mentais para explicar o comportamento que a psicologia evolutiva parece dispor de mais recursos conceituais para descrever o papel fundamental que a cultura assume na vida humana, assim como a grande variação entre indivíduos humanos no que diz respeito às suas capacidades cognitivas e afetivas, sejam estas sociais ou não.

Dessa forma, ainda que a psicologia evolutiva preserve da sociobiologia os compromissos com uma explicação biológica evolucionista do comportamento (social) humano, cujo último nível é a propagação genética e, como consequência disso, defenda a 
existência de certos mecanismos inatos universalmente compartilhados pela espécie humana, ela pode explicar como esses mecanismos podem gerar respostas distintas em seres humanos distintos, dadas as variações ambientais e culturais. Como tal, a psicologia evolutiva parece conceder espaço fundamental à cultura na explicação da vida humana. Em especial, é importante para psicólogos evolutivos que vários dos mecanismos psicológicos que explicam nossas disposições psicológicas e nossos comportamentos sejam entendidos como resultados adaptativos do nosso passado evolutivo, quando nossos ancestrais enfrentavam dificuldades distintas e desenvolviam-se em ambientes distintos dos atuais. Muitos dos nossos comportamentos modernos são, assim, explicados por psicólogos evolutivos como sendo efeitos "colaterais" do nosso passado adaptativo, em que mecanismos psicológicos que cumpriram funções adaptativas no passado não necessariamente o fazem em nossos cenários atuais. A despeito disso, é verdade que ao menos parte de nosso comportamento cultural sofre influência dos mecanismos psicológicos que herdamos de um processo evolutivo de nossa natureza e que é explicado, em última instância, no nível genético. ${ }^{19}$

Em filosofia, esses vários movimentos científicos foram absorvidos sobretudo com base nos escritos de Michael Ruse (e nas discussões provocadas por ele). No tópico que nos interessa aqui, Ruse deixa claro que uma abordagem evolucionista do fenômeno moral pode ser eficaz do ponto de vista explicativo, mas não do ponto de vista da justificação do conteúdo da moralidade. Como exatamente isso se dá?

\section{O legado filosófico da sociobiologia e da psicologia evolucionista}

Mesmo que admitamos que Moore tenha apresentado uma forte objeção (embora não conclusiva) aos primeiros projetos de uma ética evolucionista, é verdade, por outro lado, que nada do que Moore disse torna irrelevante uma investigação do fenômeno moral sob uma perspectiva evolucionista. A dificuldade apresentada por Moore dizia respeito especificamente a uma proposta de redução direta dos termos morais - e, por extensão, do conteúdo da moralidade - a princípios e dados fornecidos pela teoria evolucionista. Assim, ainda que o resultado disso fosse rejeitar que o conteúdo da moralidade pudesse ser justificado pela teoria evolucionista, nada no argumento de Moore 
20. Reações contrárias contemporâneas a essa retomada também surgiram, como Nagel (1978).

21. Ruse, 1984, p. 169 .

22. Ruse, 1986b, 237. exclui a possibilidade de que se possa explicar (ao menos em parte) nossas tendências morais com base em premissas evolucionistas. Por soar mais promissor, esse foi o ponto de partida da literatura filosófica em sua retomada recente do tema. ${ }^{20}$

O que significa tomar a teoria da evolução como ponto de partida para explicar tendências morais? Em termos gerais iniciais, podemos dizer que a hipótese relevante defende que várias de nossas capacidades psicológicas e comportamentos morais são traços adaptativos da espécie humana. Em outros termos, uma explicação possível para o surgimento e a importância que a moralidade adquiriu na vida humana está relacionada à vantagem adaptativa que o fenômeno moral gerou para a espécie humana, em termos de sobrevivência e reprodução. Mas como explicar mais claramente essa história?

A primeira dificuldade para evolucionistas foi responder à seguinte questão: "se a seleção natural diz respeito ao indivíduo, se ela se dá por egoísmo (selfishness), como se explica a ampla cooperação ou 'altruísmo' disseminado no mundo animal?”" ${ }^{21}$ A resposta que se tornou padrão para sociobiólogos e psicólogos evolucionistas consiste em identificar dois mecanismos que se revelaram compatíveis com a seleção individual: seleção por parentesco e altruísmo recíproco. Como diz Ruse:

[Na seleção por parentesco] parentes compartilham cópias dos mesmos genes. Assim, quando um parente reproduz, o indivíduo se reproduz vicariamente, por assim dizer. Portanto, ajuda dada a parentes quanto a sobrevivência e reprodução repercute em benefício ao próprio indivíduo. Há também o altruísmo recíproco. Resumidamente, se eu ajudo você (mesmo quando você não é parente) aumentam-se as chances de você me ajudar - e viceversa. Ambos ganhamos, enquanto que, separados, ambos perdemos..$^{22}$

Assim, a ideia é a de que, por meio de um processo de seleção natural, estratégias cooperativas de reciprocidade tornaram-se, ao longo do tempo, traços selecionados inicialmente, para parentes, posteriormente, para não parentes - que ampliaram a capacidade de sobrevivência e de reprodução individual, após longo processo, também grupal e, como último estágio, da espécie. Essa caracterização carece, obviamente, de maiores esclarecimentos.

Um primeiro ponto de esclarecimento consiste em fazer notar que tais mecanismos devem ser chamados de altruístas apenas de modo metafórico. Como qualquer outra adaptação, trata-se de um processo “cego”, não teleológico. Como diz Ruse: “[...] quando se fala de 'altruísmo animal' está se falando de comportamentos instintivos, 
selecionados pelo fato de seus portadores maximizarem por meio deles as suas capacidades de transmissão genética."23

Um segundo ponto consiste em propor que, em seres humanos, aquele sentido metafórico de "altruísmo" evoluiu para um sentido literal. Para autores como Ruse, o altruísmo moral (literal) foi a forma como o altruísmo biológico (metafórico) foi realizado em humanos:

O altruísmo moral, literal, é uma forma impressionante através da qual a cooperação biológica vantajosa é alcançada. Humanos são o tipo de animal que se beneficiam biologicamente da cooperação dentro de seus grupos, e o altruísmo moral, literal, é a maneira através da qual se alcança aquele fim. ${ }^{24}$

Um terceiro ponto de esclarecimento - sugerido por Ruse, mas desenvolvido de modo mais completo por autores posteriormente - consiste em chamar a atenção para o caráter categórico que as estratégias cooperativas de reciprocidade adquiriram no processo adaptativo de humanos. Richard Joyce, ${ }^{25}$ por exemplo, enfatiza que a importância que a moralidade adquiriu na vida humana pode ser explicada por meio da postulação de um sentimento de obrigação diante de estratégias cooperativas compartilhadas. ${ }^{26}$ Com esse sentimento ou senso de obrigação surgem dois outros mecanismos punitivos: um autorreferente; outro direcionado a parceiros de vida social. O mecanismo punitivo autorreferente indica as sanções de "consciência" que o próprio indivíduo experimentaria por violar uma regra compartilhada em seu grupo. O mecanismo direcionado a parceiros sociais revela, por sua vez, estratégias de detecção e punição daqueles que violam regras compartilhadas. ${ }^{27}$

Com o desenvolvimento dessas relações cooperativas, reforçadas por padrões de reciprocidade e de internalização de regras compartilhadas socialmente, associadas à crescente complexidade dos cenários práticos com os quais nossos antepassados evolutivos depararam, é provável que um novo fenômeno tenha surgido, nos moldes da seguinte descrição de Joyce:

Ao fornecer uma estrutura a partir da qual as ações de um indivíduo e as dos outros podem ser avaliadas, juízos morais podem atuar como um tipo de "moeda corrente" para negociação coletiva e deliberação. Juízos morais podem, assim, funcionar como um tipo de "aglutinação" social, atrelando indivíduos em uma estrutura justificatória compartilhada e fornecendo uma ferramenta para solucionar vários problemas grupais de coordenação. ${ }^{28}$

25. Cf. Joyce (2001; 2007).

26. Isso, por si só, parece ser um problema para se falar de "altruísmo". Quando se fala de sentimentos de obrigação com relação a estratégias cooperativas de reciprocidade não é absolutamente claro que o conceito "altruísmo" seja o mais adequado para descrever as relações em jogo.

27. Cf. Tooby e Cosmides (2004).

28. Joyce, 2007, p. 117 
Um quarto e último ponto de esclarecimento diz respeito ao poder explanatório que os diversos mecanismos postulados adquirem na psicologia e no comportamento humanos. O fato de serem, por assim dizer, “inatos”, resultantes de um processo adaptativo da espécie humana, não significa que eles necessariamente se manifestarão em todos os seres humanos e muito menos que se manifestarão de modo idêntico. Como diz Joyce, falar de automatismo (hardwiring) e inatismo, além de metafórico, é enganador, pois

leva a negligenciar a ideia de que a seleção natural nos forneceu disposições psicológicas que exigem condições ambientais para se "manifestarem". Assim, mesmo que algo muito particular como "a crença de que $p$ " pudesse ter sido selecionada, não se seguiria que todo indivíduo acredita que $p^{29}$

Feitos esses esclarecimentos, cabe agora perguntar pelas consequências filosóficas de se entender o surgimento do fenômeno moral nesses termos. A hipótese formulada aqui é obviamente muito geral e carece de detalhes relevantes para se compreender mais

30. Para uma descrição detalhada e empiricamente informada, ver Joyce (2007)

31. A capacidade linguística é particularmente importante para Joyce, que defende a hipótese de que ela é central para o fenômeno moral (por tornar possível explicar o tipo de complexidade mental que conceitos morais parecem

exigir) - sobretudo por essa razão a moralidade é um fenômeno tipicamente humano. precisamente o desenvolvimento do fenômeno moral..$^{\circ}$ Não obstante, tal hipótese geral será suficiente para nossos propósitos (igualmente gerais) de explorar algumas questões filosóficas relevantes do ponto de vista ontológico, semântico e epistemológico.

Para autores como Ruse e Joyce, tal explicação do surgimento do fenômeno moral na vida humana fornece um forte argumento a favor da tese de que não existe justificação última para a moralidade e que esta não é, em sentido estrito, objetiva. Segundo esses autores, a explicação evolucionista para o surgimento do fenômeno moral não é ela mesma de forma alguma moral. Como vimos, ela é uma explicação baseada em considerações sobre as vantagens adaptativas do comportamento moral, em termos de sobrevivência e reprodução. É isso o que possibilita que tais autores evitem uma acusação como a de Moore a Spencer. A teoria evolucionista não justifica a moralidade, apenas explica o surgimento do fenômeno moral. Assim, autores como Ruse e Joyce pensam que a melhor explicação é, na verdade, entender a moralidade como "subjetiva", no sentido de que ela se constitui fundamentalmente como o reflexo de certas disposições (psicológicas, comportamentais e, possivelmente, linguísticas) ${ }^{3 \mathrm{I}}$ adquiridas por sua eficiência adaptativa, mas sem serem respostas racionais ao mundo.

Por outro lado, uma proposta como essa enfrenta a seguinte dificuldade: parece que o modo como temos a experiência do fenômeno moral aponta para algo objetivo e não apenas subjetivo. Em outros termos, quando falamos e pensamos moralmente, 
falamos e pensamos como se realidades morais realmente existissem. Mas, se a hipótese de Ruse e Joyce estiver correta, essas realidades morais, na verdade, não existem objetivamente. Diante disso, autores como Ruse e Joyce respondem defendendo simplesmente que a aparência de objetividade da moralidade pode também ser explicada como uma adaptação. Os mecanismos subjacentes ao fenômeno moral foram provavelmente muito mais eficazes do ponto de vista evolutivo ao conferirem fenotipicamente a aparência de objetividade ao pensamento (e ao discurso) moral. Assim, Ruse diz que "não há justificação racional para a ética no sentido de existirem fundamentos aos quais se apelar em uma argumentação racional. Tudo o que se pode oferecer é um argumento causal que mostra por que possuímos crenças Para autores como Ruse e Joyce, tal explicação do surgimento do fenômeno moral na vida humana éticas." ${ }^{2}$ Mas, uma vez que a ética é um fenôme-

a favor da tese de que não existe justificação".última para a moralidade e que no existente, a melhor explicação agora disponível para o evolucionista é dizer que “a ética é uma ilusão coletiva da espécie humana, moldada e preservada pela seleção natural a fim de promover a reprodução individual"33 e que o sentido dessa ilusão é a função biológica de "nos persuadir de que a ética possui uma referência objetiva" e, assim, ser mais eficiente evolutivamente. ${ }^{34}$

Há vantagens nessa interpretação do fenômeno moral, que podemos chamar de ficcionalista (por ela entender a moralidade, em termos gerais, como uma ficção útil do ponto de vista evolutivo). Ela evita a acusação da falácia naturalista de Moore, mostrando como a teoria evolucionista em si mesma deve ser entendida, ou seja, desprovida de conteúdo moral, ao mesmo tempo em que explica como o fenômeno moral adquiriu a importância que identificamos na vida humana. Mas há, por outro lado, também dificuldades. Mencionaremos aqui duas delas: em primeiro lugar, cabe ao ficcionalista explicar como lidar com a identificação do erro sistemático que a ficção na qual nos encontramos gera - ou seja, o erro de tomar como verdadeiro e objetivo algo que não é - quando pensamos e falamos moralmente. Ruse parece não perceber o ar paradoxal quando diz que "embora nossos poderes racionais nos mostrem que não existe moralidade objetiva, todos nós, como humanos, sentimos que existe.”35 Ao descobrir que 35. Ruse, 1984, p. 192. 
36. A estratégia mais comum entre ficcionalistas consiste em conferir à moralidade valor instrumental, como meio para a promoção dos interesses dos indivíduos, estes, sim, passíveis de atribuição de valor genuíno (não ficcional).

37. Como veremos, essa acusação se direciona mais a um autor como Ruse do que a um autor como Joyce. 38. Cf. Ruse, 1984.

nosso discurso e pensamento morais não realizam aquilo que se propõem a realizar - a saber, a representação de uma realidade moral objetiva - não parece que possamos mais continuar a usar os conceitos e proposições básicos da moralidade sem algum tipo de desconforto. E esse desconforto parece ser propriamente de natureza racional. Afinal, confortarmo-nos em pensar e falar sobre algo como verdadeiro, quando sabemos agora que é uma ficção, parece uma atitude irracional. Supondo, então, que, não estando dispostos a abandonar completamente o discurso moral - por identificarem algum valor nele -, os ficcionalistas precisam de alguma justificativa ulterior para continuar a pensar e falar moralmente (já que fazer isso, por si só, é uma mera ficção) e removerem a acusação de irracionalidade. ${ }^{6}$

O segundo problema diz respeito ao fato de que, embora o ficcionalista rejeite qualquer justificação última do conteúdo da moralidade, ele parece endossar um conjunto de disposições e comportamentos que seriam efetivamente constitutivos daquilo que (supostamente) reconhecemos como moral. ${ }^{77}$ Por exemplo, Ruse (seguindo os sociobiólogos) defende um papel central para o altruísmo naquilo que (supostamente) reconhecemos como moral e defende que seria justificável moralmente parcialidades morais direcionadas àqueles que fazem parte de nosso círculo estreito de relações afetivas. ${ }^{38} \mathrm{O}$ problema aqui não é propriamente perguntar se essas propostas estão ou não de acordo com as nossas sensibilidades morais. O problema é como Ruse faz sua defesa. Ao considerar que altruísmo e parcialidade em relação ao nosso círculo estreito de relações afetivas são tendências herdadas diretamente de nosso passado evolutivo, Ruse as inclui como parte integrante de nossos princípios morais com algum tipo de legitimidade simplesmente porque são herdadas de nosso passado evolutivo. Mas, nesse ponto, não é mais tão claro que Ruse esteja em posição muito melhor do que Spencer. Afinal, embora ele possa dizer que nada do que pensamos que é moral esteja racionalmente justificado, ainda assim, por termos o fenômeno moral internalizado em nossas vidas, agimos como se estivéssemos justificados. E o que figurará agora em nossa “ficcional” visão moral de mundo? Na história de Ruse, exatamente aquilo que nos foi fornecido diretamente pela evolução.

Que esse ponto é um problema para Ruse fica claro na seguinte passagem, quando ele considera a crítica de que Wilson não escaparia da falácia naturalista:

Wilson não está dizendo que a natureza humana [...] é em si mesma boa porque evoluiu, 
nem está dizendo que o processo da evolução é algo bom. Ao contrário, ele está dizendo que a nossa capacidade moral evoluiu e que isso estabelece nossos padrões de certo e errado. Ela produz os objetivos que devem ou não ser alcançados. Portanto, podemos entender a moralidade apenas através do entendimento da nossa evolução. ${ }^{39}$

Se a evolução nos dotou com os padrões de certo e errado e com os objetivos que devem e que não devem ser almejados, mesmo que isso seja uma ficção, bastaria informarse na teoria evolucionista para descobrir como pensamos que devemos agir. E isso parece efetivamente ter algo em comum com aquilo que Moore chamou de "falácia naturalista".

Nas próximas duas seções, veremos possíveis respostas a esses dois problemas gerais associados à interpretação ficcionalista, mas mantendo o compromisso geral com uma explicação evolucionista do fenômeno moral na vida humana.

\section{Expressando atitudes ou construindo verdades? Alternativas ao Ficcionalismo}

Uma possível resposta ao primeiro problema consistiria em abandonar a semântica e/ou epistemologia que figuram na base da interpretação ficcionalista. Ficcionalistas normalmente defendem uma semântica descritivista para a linguagem moral, postulando que nosso discurso moral se propõe a descrever realidades genuinamente morais externas a nós. Mas, como vimos, para ficcionalistas, a melhor forma de compatibilizar uma explicação evolucionista do fenômeno moral com os compromissos descritivistas do discurso moral é concluir que este, ainda que se proponha a representar algo objetivo, simplesmente fracassa nesta tarefa e, assim, a moralidade se revela uma ficção.

Por outro lado, ficcionalistas são geralmente fundacionalistas acerca da justificação do discurso moral. Desse modo, para que um juízo moral particular esteja justificado, ele deve ser justificado por um outro juízo particular (também justificado) ou ser ele mesmo autojustificado. Assim, as proposições fundacionais (e os respectivos juízos) desse modelo epistemológico são aquelas que se justificam por si mesmas e não necessitam de justificação por outras proposições. Porém, apesar de a interpretação ficcionalista defender tal modelo, não há qualquer proposição moral fundacional na história contada por ficcionalistas. Como vimos, Ruse diz que os juízos fundacionais 
mais básicos de nosso discurso moral são simplesmente explicados causalmente, mas não justificados. Eles não são autojustificados nem são capazes de ser justificados por proposições não morais (isso seria justamente cometer a falácia naturalista). Assim, ficcionalistas concluem que nosso discurso moral não está justificado.

Uma proposta de resolução do primeiro problema pode agora ser considerada. Se for possível propor uma revisão dos compromissos semânticos do ficcionalismo, substituindo a tese de que a linguagem moral cumpre um papel descritivo pela tese de que o discurso moral não é descritivista, mas projetivista, talvez seja possível evitar o desconforto que a interpretação ficcionalista gera. Se nosso discurso não cumprisse uma função descritivista, mas meramente projetiva - isto é, de projetar sobre o mundo nossas disposições subjetivas, por meio das quais enxergamos o mundo como se fosse dotado de propriedades morais - talvez fosse possível legitimar o uso do vocabulário moral (no sentido de livrá-lo de erros) simplesmente porque ele agora não se proporia a representar nada. Para o projetivista, o discurso moral cumpre fundamentalmente um papel motivacional em nossas vidas práticas, tendo como fim último criar condições para que possamos compartilhar nossas disposições subjetivas (não cognitivas) sobre o mundo, expressas por meio do nosso vocabulário moral. Assim, nesse modelo, não há referência à verdade ou à falsidade em um sentido genuíno. A evolução pode ter-nos dotado de disposições subjetivas possíveis de ser compartilhadas e, assim, pensarmos e falarmos moralmente, mas ao fazer isso não apontamos para uma realidade

40. Contemporaneamente, não cognitivistas e expressivistas propõem algo nesses termos. O custo, porém, dessa interpretação é óbvio: ela remove a objetividade, em sentido estrito, do discurso moral. E isso pode não se acomodar bem ao nosso próprio entendimento daquilo que é constitutivo do discurso moral. objetiva que esse discurso se proporia a representar. $4^{\circ}$

Outra proposta de resolução do primeiro problema consiste em revisar o compromisso fundacionalista da interpretação ficcionalista. Se o coerentismo for uma alternativa viável para a justificação do discurso moral, seria possível justificá-lo sem apelar para proposições últimas que deveriam ser autojustificáveis. Em linhas gerais, segundo um modelo coerentista de justificação, toda proposição de um sistema é justificada apelando-se a outra proposição que lhe dá suporte e que, por sua vez, deve ser justificada por uma terceira proposição e assim por diante, indefinidamente. Não cabe aqui avaliar se esse modelo é capaz de responder a objeções clássicas, como a acusação de circularidade. Supondo que o coerentismo seja uma alternativa plausível, juízos morais se suportariam mutuamente e essa seria a única maneira de garantir justificação. O coerentista poderia agora dar um outro passo, que lhe parece um desdobramento 
natural, e defender que devemos compreender não apenas justificação, mas também verdade moral como sendo constituída pela coerência máxima entre juízos morais. Em outros termos, se um modelo de justificação coerentista implicar um modelo de verdade coerentista, então o coerentista poderia dizer que verdades morais são construídas com base na coerência interna de nossos juízos. ${ }^{4 \mathrm{I}}$ Segundo esse modelo coerentistaconstrutivista, o discurso moral poderia permanecer descritivista, porém abandonando o caráter objetivista da interpretação ficcionalista.

Como, então, essa proposta coerentista-construtivista poderia se acomodar a uma explicação evolucionista do fenômeno moral? Como as propostas anteriores, os juízos morais que formulamos seriam (ao menos em parte) resultado de um processo evolutivo, que explica o surgimento do fenômeno moral, sem que haja qualquer relação interessante de justificação entre os princípios da teoria evolucionista e o conteúdo da moralidade. Mas a proposta coerentista-construtivista tem uma explicação óbvia para isso: verdade moral é aqui entendida em termos de coerência - portanto, não depende do fato dos juízos representarem acuradamente realidades objetivas, externas a eles. Assim, ainda que a evolução tenha nos dotado com (grande parte) de nossas disposições para julgar moralmente, as disposições que serão tomadas como justificadas dependerão de um "ajuste global” com outras disposições e juízos morais - e muitos destes poderão ter surgido sob influência de processos culturais. No desenvolvimento das estratégias de justificação de nossos juízos morais, alguns juízos serão abandonados, outros (talvez não fornecidos diretamente pela evolução) incorporados. E tal discurso será verdadeiro quando ele for maximamente coerente..$^{22}$

\section{Inatismo, Plasticidade e Cultura}

Retomemos agora o segundo problema mencionado anteriormente com a interpretação ficcionalista. O problema dizia respeito ao fato de que, embora um ficcionalista como Ruse negue que nosso discurso moral esteja justificado, ele, ao mesmo tempo, parece importar diretamente para o conteúdo da moralidade aquilo que a teoria evolucionista nos diz sobre nossa psicologia e comportamento. Assim, Ruse parece entender a prática da moralidade, em grande parte, como resultado direto da atuação dos
41. Ver, porém, Brink (1989), que rejeita que coerentismo implique construtivismo
42. John Rawls é considerado o grande precursor contemporâneo do coerentismo e do construtivismo aplicados à moral e à política. Porém, apesar da grande influência de Rawls, persiste como uma dificuldade central para o construtivismo mostrar como especificar os procedimentos de ordem superior que permitem regular conflitos entre atitudes (crenças, emoções, etc.) de primeira-ordem, sem ao mesmo tempo apelar a alguma noção de valor que faça referência a uma realidade genuinamente objetiva. 
43. Como deve estar claro, esse é um problema que afeta não apenas o ficcionalista, mas também as duas outras posições que abordamos anteriormente. E, como ficará claro, a resposta ao problema que veremos a seguir está disponível a todas as três “ posições.

44. Cf. Tooby (1985); Tooby e Cosmides (1989; 2004)

45. "Dizer que naturalmente formulamos juízos morais pode significar que somos moldados para ter atitudes morais particulares com relação a tipos de coisas (por exemplo, tomar o incesto e o parricídio como moralmente ofensivos), ou pode significar que temos uma tendência a tomar uma variedade de coisas como moralmente ofensivas [...], em que o conteúdo é determinado por fatores ambientais e culturais contingentes." (Joyce, 2007, mecanismos psicológicos selecionados evolutivamente. Mas isso é, obviamente, um problema, pois, da perspectiva que reconhecemos como moral, nem todas as nossas disposições psicológicas e comportamentos explicados pela evolução são endossados. Como, então, proceder?43

Uma resposta pode advir da tese, comum a vários psicólogos cognitivos, segundo a qual os mecanismos subjacentes ao pensamento e comportamento morais humanos são aqueles que envolvem, por um lado, respostas específicas a certos tipos de ambientes e situações (nos termos da psicologia evolucionista, que eles sejam mecanismos "content-specific") e, por outro lado, capacidades altamente flexíveis e plásticas. ${ }^{44}$ Assim, ainda que certas tendências psicológicas ou respostas comportamentais possam ser automáticas (hardwired) ou inatas, admitindo pouca variação nos cenários evolutivos passados em que os mecanismos subjacentes a elas cumpriam um papel adaptativo, esses mesmos mecanismos podem, sob condições de variação ambiental e cultural, responder de maneira diversa (e até mesmo não mais adaptativa). ${ }^{45}$ Ainda assim, é possível que vários desses mecanismos preservem certas características gerais de nosso passado evolutivo. No caso do fenômeno moral, a capacidade de internalização de regras sociais compartilhadas e os sentimentos associados de reforço a elas podem ser preservados com características da psicologia de nossos ancestrais evolutivos, ao mesmo tempo em que possibilitam variação naquilo que figurará no conteúdo de tais regras ou práticas. Joyce explicita o ponto ao dizer que:

Embora a psicologia evolucionista admita que grande parte do comportamento humano observável possa ser "acidental" do ponto de vista evolutivo (no sentido de que é o resultado de mecanismos inatos atuando em um novo ambiente), ela também admite a "suposição" de que humanos são comportamentalmente maleáveis em vários aspectos - que a própria plasticidade de muitos mecanismos psicológicos é uma adaptação. ${ }^{46}$

Assim,

Ainda que não haja dúvida de que o conteúdo de qualquer moralidade seja altamente influenciado pela cultura, pode ser o caso que o simples fato de uma comunidade ser capaz de possuir uma moralidade deva ser explicado com referência a mecanismos psicológicos forjados pela seleção natural biológica. 47

Com essas afirmações, a hipótese de que a tendência ou capacidade de formular juízos morais é inata torna-se compatível com a atribuição de um papel decisivo à cultura 
humana na constituição daquilo que é constitutivo do conteúdo da moralidade. O ponto fundamental da teoria evolucionista seria, então, postular que é justamente por possuirmos mecanismos inatos específicos que se torna possível pensar e falar moralmente, e que fazemos isso com nossas visões de mundo moldadas por processos culturais..$^{8}$

Porém, apesar de elementos tipicamente culturais serem provavelmente responsáveis por moldar grande parte do conteúdo da moralidade, nada exclui que possamos, ainda assim, ter importado diretamente alguns elementos característicos de nosso passado evolutivo "proto-moral". Para Joyce, muito provavelmente o elemento central a ser assimilado por aquilo que reconhecemos como moral é a noção de reciprocidade, entendida em sentido amplo:

[...] um dado clamoroso é que todos os sistemas morais humanos conferem um papel central a relações recíprocas; se o senso moral humano foi formado para certo conteúdo, é exatamente este. Parece, assim, bastante razoável supor que trocas recíprocas foram um problema central para a evolução ao qual a moralidade foi destinada a resolver. ${ }^{49}$

Como evidência da ubiquidade dessas relações de reciprocidade, Joyce cita nosso interesse em boa reputação, nossa capacidade de distinguir danos acidentais de danos intencionais (e de tender a relevar os primeiros), nossa sensibilidade a trapaças e antipatia por aqueles que as praticam (e frequentemente a tendência associada de puni-los, mesmo quando isso envolve custos a nós mesmos), um forte senso de posse, além de sensibilidade a questões distributivas (de custos e benefícios). Todas essas tendências, segundo Joyce, parecem incorporar relações de reciprocidade. Dada, então, essa hipótese, é possível que vários mecanismos de "proto-reciprocidade" tenham-se desenvolvido e transmutado nos mecanismos subjacentes àquelas tendências e que estas, por sua vez, tenham sido de alguma forma incorporadas (remodeladas e redimensionadas) no conteúdo daquilo que reconhecemos como moral..$^{\circ}$

Uma vez feitas essas distinções, torna-se mais claro como é possível evitar incorrer em algo como a falácia naturalista. Mesmo que se explique o fenômeno moral como tendo sido gerado por uma série de mecanismos psicológicos com respostas específicas a certas circunstâncias ambientais, esses mecanismos tendem a fornecer respostas distintas diante de estímulos distintos (incluindo aqui variações culturais). Assim, o conteúdo da moralidade, tal como nós a reconhecemos, pode ser em grande escala um subproduto ou aspecto acidental do processo evolutivo. Nesse sentido, possuiríamos os
48. Cf. Joyce, 2007 , p. 137
50. Ibid. É a possibilidade de que tais tendências tenham sido remodeladas e redimensionadas por um processo crescente de complexidade das interações humanas que permite que reconheçamos como morais várias relações de não reciprocidade como por exemplo, deveres com relação a crianças, idosos, portadores de necessidades especiais e animais. 
51. Symons, 1992, p. 138. 52. Joyce, 2007, p. 107.

recursos conceituais necessários para distinguir o papel que os mecanismos psicológicos responsáveis pelo surgimento do fenômeno moral cumpriram em nosso passado evolutivo - por sua vantagem adaptativa - do papel que os mesmos mecanismos (associados a outros mecanismos mediados por elementos culturais) cumprem atualmente na vida moral humana. Assim, não há nada naquilo que reconhecemos atualmente como moral que precise cumprir qualquer função adaptativa. Um erro comum nessa discussão é “confundir o processo geral que produz adaptações com as próprias adaptações." ${ }^{\mathrm{I}}$ Mas, como diz Joyce, é importante que a questão seja formulada corretamente, "pois não estamos tentando descobrir como a moralidade é adaptativa, mas como ela poderia ter-se tornado uma adaptação - isto é, como ela foi adaptativa." ${ }^{2}$

\section{Conclusão}

Iniciamos nossa discussão perguntando pela possibilidade e pela relevância de uma explicação evolucionista do fenômeno moral. Exploramos o tema com base na hipótese de que tal explicação não forneceria justificação última para o discurso moral. Abordamos três correntes de pensamento filosófico que endossam essa hipótese, mas que fornecem diferentes caracterizações dos compromissos conceituais do discurso moral. Ao longo de nossa discussão, procuramos indicar formas de responder ao questionamento de Nagel, que tomamos como nosso ponto de partida. Ao contrário da sugestão de Nagel, tentamos mostrar como uma explicação evolucionista da moralidade pode não apenas ser útil como forma de compreender como seres humanos pensam e se comportam, mas igualmente redimensionar nosso entendimento daquilo que é o discurso moral. Nossas considerações finais sugerem que uma dicotomia radical entre natureza e cultura humanas como forma de explicar o pensamento e o comportamento humanos é provavelmente equivocada, e que a melhor maneira de entendermos um fenômeno tipicamente humano como a moralidade consiste em identificar uma interdependência entre dados empíricos sobre nossa natureza (por exemplo, sobre nosso passado evolutivo) e o surgimento de nossas visões de mundo, por meio de manifestações culturais. Assim, mostramos como uma explicação evolucionista do fenômeno moral pode oferecer uma contribuição significativa na direção de uma resposta à questão sobre o que é a moralidade. 
Um projeto como esse é reconhecidamente muito geral e especulativo. Mas isso, por si só, não deve desqualificá-lo, pois os desdobramentos da versão contemporânea da teoria evolucionista são ainda embrionários em muitos aspectos.

\section{Referências}

BARKOW, J. H., Cosmides, L. Tooby, J. The Adapted Mind: Evolutionary Psychology and the Generation of Culture, Oxford: Oxford University Press, I992.

BRINK, D. Moral Realism and the Foundations of Ethics, Cambridge: Cambridge University Press, I989.

FRANKENA, W. 'The Naturalistic Fallacy’, Mind, 48, I939.

JOYCE, R. The Evolution of Morality, Cambridge, MA: MIT Press, 2007.

JOYCE, R. The Myth of Morality, Cambridge: Cambridge University Press, 200I.

MOORE, G.E. Principia Ethica. Moore, New York: Dover, 2004/1903.

NAGEL, T. 'Ethics as an Autonomous Theoretical Subject', in G. Stent, Morality as a Biological Phenomenon, Berkeley: University of California Press, I978.

RUSE, M. 'The Morality of the Gene', The Monist, 67 (2): 167-199, I984.

RUSE, M. Levando Darwin a Sério, Belo Horizonte: Editora Itatiaia, I995/1986a.

RUSE, M. 'Evolutionary Ethics: a Phoenix Arisen', Zygon, 2I: 95-II2, I986b.

SYMONS, 'On the Use and Misuse of Darwinism in the Study of Human Behavior', in Barkow et al, I37-I59, I992.

SPENCER, H. The Data of Ethics, New York: D. Appleton and Company, I882/1879.

TOOBY, J. 'The Emergence of Evolutionary Psychology', in D. Pines (ed.), Emerging Syntheses in Science, Santa Fe: Santa Fe Institute, 1985.

TOOBY, J., Cosmides, L. 'Evolutionary Psychology and the Generation of Culture, Part I', Ethology and Sociobiology, I0: 29-49, 1989.

TOOBY, J., Cosmides, L. 'Knowing Thyself: The Evolutionary Psychology of Moral Reasoning and Moral Sentiments', Society for Business Ethics, 9I-I27, 2004.

WILSON, E. O. Sociobiology: The New Synthesis, the abridged edition, MA: Harvard University Press, I975.

WILSON, E. O. On Human Nature, Cambridge, MA: Harvard University Press, I978. 